\title{
Kualitas Yoghurt Sinbiotik Dengan Kombinasi Tepung Kimpul (Xanthosoma sagittifolium) dan Sari Buah Mangga (Mangifera indica var. arumanis)
}

\section{Quality of Sinbiotic Yoghurt with Combination of Cocoyam Flour (Xanthosoma sagittifolium) and Mango Juice (Mangifera indica var. arumanis) Combinations}

\author{
Ngatini $^{1}$, Ekawati Purwijantiningsih ${ }^{1 *}$, F. Sinung Pranata ${ }^{1}$ \\ ${ }^{1}$ Fakultas Teknobiologi, Universitas Atma Jaya Yogyakarta, Yogyakarta \\ E-mail: purwija@mail.uajy.ac.id *Penulis untuk korespondensi
}

\begin{abstract}
Sinbiotic yoghurt is yoghurt made up of probiotic and prebiotic combinations. Cocoyam (Xanthosoma sagittifolium) contains bioactive diosgenin compounds and inulin that can be used as a substrate for probiotic growth. Mango (Mangifera indica) contains glucose that can be probably be utilized for the growth of lactic acid bacteria (LAB). Lactic acid bacteria (LAB) added as starter were Lactobacillus acidophilus and Bifidobacterium longum. This study aims to determine the effect of cocoyam flour and mango juice combinations (C:M) on physical, chemical, microbiological, and organoleptic qualities and to obtain optimum concentration of the combination $(\mathrm{C}: \mathrm{M})$ which produces best quality of sinbiotic yoghurt. This research was done using completely randomized design with 4 concentration treatments $(\mathrm{C}: \mathrm{M})$ 10:4\%, 7:7\%, 4:10\%, and 0:0 with three replications. Observed variables consist of color, LAB viability, Salmonella, fat content, protein, soluble fiber, acidity $(\mathrm{pH})$, total lactic acid, reducing sugar and organoleptic test. Data were analyzed by ANOVA continued by Duncan test. The results showed that the addition of $(\mathrm{C}: \mathrm{M})$ significantly affected the increasing of LAB viability, reducing sugar content, acidity $(\mathrm{pH})$, and lactic acid. The addition of $(\mathrm{C}: \mathrm{M})$ 4: $10 \%$ produced good quality sinbiotic yoghurt which were most preferred by panelists with result of sour taste, semi solid texture, LAB viability $1 \times 10^{9} \mathrm{CFU} / \mathrm{ml}$, negative Salmonella, $1,69 \%$ fat content, $3,55 \%$ protein content, 2,36\% soluble fiber content, 1,48\% lactic acid levels and pH 4.
\end{abstract}

Keywords: Sinbiotic yoghurt, Probiotic, Prebiotic, Cocoyam, Mango, Bifidobacterium, Lactobacillus acidophilus

Abstrak

Yoghurt sinbiotik merupakan yoghurt yang dibuat dengan mengombinasikan probiotik dan prebiotik. Kimpul (Xanthosoma sagittifolium) mengandung senyawa bioaktif diosgenin dan inulin yang digunakan sebagai substrat untuk pertumbuhan probiotik. Mangga (Mangifera indica) mengandung glukosa yang dapat dimanfaatkan untuk pertumbuhan bakteri asam laktat (BAL). Bakteri asam laktat (BAL) yang ditambahkan sebagai starter yakni Lactobacillus acidophilus dan Bifidobacterium longum. Penelitian ini bertujuan mengetahui pengaruh penambahan kombinasi tepung kimpul dan sari buah mangga (K:M) terhadap kualitas fisik, kimia, mikrobiologis, organoleptik dan mendapatkan konsentrasi optimum penambahan kombinasi (K:M) yang menghasilkan kualitas yoghurt sinbiotik yang paling baik. Penelitian ini menggunakan Rancangan Acak Lengkap (RAL) dengan 4 perlakuan kombinasi (K:M) sebanyak 10:4\%, 7:7\%, 4:10\%, dan 0:0\% dengan 3 kali ulangan. Variabel yang diamati meliputi warna, viabilitas BAL, salmonella, kadar lemak, protein, serat larut, derajat keasaman (pH), total asam laktat, gula reduksi dan uji organoletik. Data dianalisis dengan ANOVA, dilanjutkan dengan uji Duncan. Hasil penelitian menunjukkan bahwa penambahan (K:M) berpengaruh nyata terhadap peningkatan viabilitas BAL, kadar gula reduksi, derajat keasaman (pH), dan kadar asam laktat. Penambahan kombinasi (K:M) 4:10\% menghasilkan kualitas yoghurt sinbiotik yang baik, paling disukai oleh panelis dengan rasa asam, tekstur semisolid, viabilitas BAL 1 x $109 \mathrm{CFU} / \mathrm{ml}$, negatif Salmonella, kadar lemak 1,69\%, kadar protein $3,55 \%$, kadar serat larut $2,36 \%$, kadar asam laktat $1,48 \%$ dan pH 4 .

Kata kunci: Yoghurt sinbiotik, Probiotik, Prebiotik, Kimpul, Mangga, Bifidobacterium, Lactobacillus acidophilus

Diterima: 5 Januari 2018, disetujui: 4 Februari 2018 


\section{Pendahuluan}

Istilah sinbiotik digunakan pada produk yang mengandung probiotik dan prebiotik. Menurut Lesniewska dkk. (2006) yoghurt sinbiotik merupakan yoghurt dengan kombinasi probiotik dan prebiotik. Lactobacillus acidophilus dan Bifidobacterium spp. merupakan bakteri asam laktat dan digolongkan sebagai probiotik yang diketahui memiliki ketahanan yang baik dalam saluran pencernaan manusia (Gomez dan Malcata, 1999).

Kimpul (Xanthosoma sagittifolium) mengandung senyawa bioaktif diosgenin dan Polisakarida Larut Air (PLA) yang merupakan kumpulan dari inulin yang dapat digunakan sebagai substrat untuk pertumbuhan probiotik (Jatmiko dkk., 2014). Menurut penelitian Senditya dkk. (2014), serat larut air yang berasal dari tanaman cincau hitam berpotensi sebagai prebiotik yang dapat dimanfaatkan oleh bakteri probiotik.

Pada pembuatan yoghurt biasanya ditambahkan buah yang dapat meningkatkan kualitas rasa dan warna. Mangga arumanis (Mangifera indica var. arumanis) merupakan salah satu buah yang banyak disukai dan dikonsumsi oleh masyarakat karena memiliki rasa yang manis karena kandungan gula yang tinggi yakni 35,83\% (Kartikorini, 2016) dan aroma yang harum. Kandungan glukosa dalam buah mangga diduga dapat digunakan oleh BAL untuk peningkatan pertumbuhan dan aktivitasnya (Hidayat dkk., 2013).

Tujuan penelitian ini adalah menentukan kombinasi tepung kimpul dan sari buah mangga yang tepat untuk memperoleh yoghurt sinbiotik dengan kualitas (sifat fisik, kimia, mikrobiologis dan organoleptik) terbaik sehingga dapat menunjang pemenuhan kebutuhan konsumsi masyarakat terhadap bahan pangan fungsional.

\section{Metode Penelitian}

Penelitian dilaksanakan pada bulan Oktober 2017 hingga Desember 2017 di Laboratorium Teknobiologi Pangan dan Laboratorium Produksi, Fakultas Teknobiologi Universitas Atma Jaya Yogyakarta. Rancangan percobaan yang digunakan pada penelitian ini yaitu Rancangan Acak Lengkap (RAL) dengan empat jenis variasi kombinasi tepung kimpul dan sari buah mangga A (10:4), B (7:7), C (4:10), dan $\mathrm{K}(0: 0) \%$, dengan pengulangan sebanyak 3 kali. Tahapan penelitian ini terdiri dari pembuatan sari buah mangga, uji proksimat tepung kimpul dan sari buah mangga, uji kemurnian dan perbanyakan isolat bakteri Lactobacillus acidophilus dan Bifidobacterium longum, pembuatan starter, pembuatan yoghurt, uji kualitas mikrobiologis, uji kualitas fisik, uji kualitas kimia, uji organoleptik, dan analisis data.

\section{Hasil dan Pembahasan}

\section{Analisis Proksimat Tepung Kimpul (Xanthosoma sagittifolium) dan Sari Buah Mangga (Mangifera indica var. arumanis)}

Berdasarkan penelitian, diketahui bahwa kadar abu tepung kimpul sebesar 5,73\%, sedangkan kadar lemak 4\%, kadar protein $4,56 \%$ dan kadar serat larut sebesar $1,57 \%$ (Tabel 1). Hasil tersebut agak berbeda dengan hasil penelitian Pangaribuan (2013) dan Jatmiko (2013). Berdasarkan penelitian Jatmiko (2013), kadar abu tepung kimpul sebesar 5,73\%, sedangkan kadar lemak 1,69\%, kadar protein $5,03 \%$ dan kadar serat larut berdasarkan penelitian Jatmiko (2013) sebesar 1,92\%.

Tabel 1. Hasil Uji Proksimat Tepung Kimpul (Xanthosoma sagittifolium)

\begin{tabular}{lcc}
\hline \hline \multicolumn{1}{c}{ Parameter } & Hasil Uji & $\begin{array}{c}\text { Kandungan Gizi Tepung Kimpul per 100 g } \\
\text { (berdasarkan literatur) }\end{array}$ \\
\hline \hline Kadar Abu & $3,97 \%$ & $5,73 \%^{1}$ \\
Kadar Lemak & $4 \%$ & $1,69 \%^{1}$ \\
Kadar Protein & $4,56 \%$ & $5,03 \%^{1}$ \\
Kadar Serat Larut & $1,57 \%$ & $1,92 \%^{2}$ \\
\hline \hline
\end{tabular}

Keterangan: ${ }^{1}$ Pangaribuan (2013), ${ }^{2}$ Jatmiko (2013) 
Hasil penelitian pada sari buah mangga arumanis menunjukkan kadar abu sebesar $0,32 \%$, kadar lemak $0,36 \%$, kadar protein $0,58 \%$, kadar serat $0,46 \%$ dan kadar gula reduksi 3,3\% (Tabel 2). Hasil penelitian yang diperoleh tidak jauh berbeda dengan data Departemen Kesehatan RI (1972) yang menunjukkan kadar abu 0,36\%, kadar lemak $0,2 \%$, kadar protein $0,4 \%$, sedangkan kadar serta larut $1,0 \%$ (Ramulu dan Rao, 2003) dan kadar gula reduksi 3\% (Hossain dkk., 2014).

Hasil uji proksimat yang berbeda dapat dipengaruhi oleh perbedaan tingkat kesuburan tanah. Menurut Abdurachman dkk. (2008), setiap daerah pada dasarnya memiliki tingkat kesuburan tanah yang berbeda-beda dan masa panen yang berbeda sehingga mempengaruhi kadar bahan organik. Umumnya lahan yang kering memiliki tingkat kesuburan tanah yang rendah dan kadar bahan organiknya juga ikut rendah.

\section{Uji Kemurnian Bakteri Lactobacillus acidophilus dan Bifidobacterium longum}

Berdasarkan Tabel 3 dan Tabel 4, uji kemurnian terhadap Lactobacillus acidophilus dan Bifidobacterium longum diperoleh hasil yaitu memiliki bentuk sel batang, Gram positif, non-motil, dan katalase negatif. Hasil pengamatan Lactobacillus acidophilus tersebut telah sesuai dengan literatur menurut Purwandhani dan Rahayu (2003) yang menyatakan bahwa bentuk sel Lactobacillus acidophilus adalah batang, pengecatan Gram positif, katalase negatif, dan non-motil. Hasil pengamatan Bifidobacterium longum juga telah sesuai dengan literatur menurut Du dkk., (1998) yang menyatakan bahwa Bifidobacterium longum merupakan bakteri Gram positif, bentuk sel batang bercabang, anaerobik obligat, non motil, dan katalase negatif. Berdasarkan hasil tersebut maka bakteri Lactobacillus acidophilus dan Bifidobacterium longum yang digunakan dalam pembuatan yoghurt sinbiotik dapat dinyatakan benar murni bakteri Lactobacillus acidophilus dan Bifidobacterium longum.

\section{Analisis Fisik Yoghurt Sinbiotik}

Hasil menunjukkan bahwa produk $\mathrm{K}(0: 0)$, $\mathrm{C}(4: 10), \mathrm{B}(7: 7)$, dan $\mathrm{A}(10: 4)$ dari interpretasi color reader diperoleh hasil warna sumber cahaya adalah putih pada seluruh produk (Tabel 5), sedangkan dari interpretasi mata produk $\mathrm{K}(0: 0), \mathrm{C}(4: 10), \mathrm{B}(7: 7), \mathrm{A}(10: 4)$ menunjukkan warna secara berurutan yakni putih krem, putih kekuningan, putih kuning kecoklatan dan putih kecoklatan. Warna putih kecoklatan tersebut berasal dari tepung kimpul.

Warna yoghurt yang dihasilkan perlakuan A(10:4), B(7:7), C(4:10) ke arah kuning, hal ini dipengaruhi oleh penambahan sari buah mangga yang mengandung karotenoid. Menurut Coulate (2009), pigmen karotenoid bertanggung jawab untuk kebanyakan warna kuning dan orange dari buah-buahan dan sayuran. Secara khusus golongan karotenoid yang memberikan pigmen dominan pada jaringan kuning adalah xanthophylls, sedangkan warna orange dan merah terang adalah karoten.

\section{Analisis Kualitas Mikrobiologi Yoghurt Sinbiotik}

\section{Analisis Nilai Viabilitas BAL Yoghurt Sinbiotik}

Hasil viabilitas BAL pada produk $\mathrm{K}(0: 0)$, $\mathrm{C}(4: 10), \mathrm{B}(7: 7)$, dan $\mathrm{A}(10: 4)$ secara berurutan yakni 7,75; 9,018; 10,16 dan 9,97 $\log \mathrm{CFU} / \mathrm{mL}$ (Tabel 6). Hasil tersebut menunjukkan adanya perbedaan nyata antara yoghurt yang diberi perlakuan tepung kimpul dan sari buah mangga dengan yang tidak diberi perlakuan (kontrol). Menurut Badan Standarisasi Nasional (2009), syarat mutu jumlah bakteri starter (BAL) pada yoghurt adalah minimal $10^{7} \mathrm{CFU} / \mathrm{mL}$ atau $7 \mathrm{log}$ $\mathrm{CFU} / \mathrm{mL}$. Berdasarkan hasil pengujian viabilitas BAL pada yoghurt sinbiotik diperoleh hasil viabilitas BAL berkisar 7,75 - 9,97 log CFU/mL, sehingga produk yoghurt yang dihasilkan dari penelitian ini telah sesuai dan memenuhi standar SNI syarat mutu yoghurt dan konsumsi produk yoghurt sinbiotik ini dapat memberikan efek kesehatan bagi tubuh. 
Kualitas Yoghurt Sinbiotik Kombinasi Tepung Kimpul dan Sari Buah Mangga

Tabel 2. Hasil Uji Proksimat Sari Buah Mangga (Mangifera indica var. arumanis)

\begin{tabular}{lcc}
\hline \hline \multicolumn{1}{c}{ Parameter } & Hasil Uji & $\begin{array}{c}\text { Kandungan Gizi Sari Buah Mangga per 100 g } \\
\text { (berdasarkan literatur) }\end{array}$ \\
\hline \hline Kadar Abu & $0,32 \%$ & $0,36 \%{ }^{1}$ \\
Kadar Lemak & $0,36 \%$ & $0,2 \%{ }^{1}$ \\
Kadar Protein & $0,58 \%$ & $0,4 \%{ }^{1}$ \\
Kadar Serat Larut & $0,46 \%$ & $1,0 \%{ }^{2}$ \\
Kadar Gula Pereduksi & $3,3 \%$ & $3 \%{ }^{3}$ \\
\hline \hline
\end{tabular}

Keterangan : ${ }^{1}$ Departemen Kesehatan RI (1972), ${ }^{2}$ Ramulu dan Rao (2003), ${ }^{3}$ Hossain dkk., (2014)

Tabel 3. Hasil Uji Kemurnian Lactobacillus acidophilus

\begin{tabular}{lll}
\hline \hline \multicolumn{1}{c}{ Uji } & \multicolumn{1}{c}{ Hasil Uji } & \multicolumn{1}{c}{ Purwandhani dan Rahayu (2003) } \\
\hline \hline Bentuk Sel & Batang & Batang \\
Pengecatan Gram & Positif & Positif \\
Motilitas & Non-motil & Non-motil \\
Katalase & Negatif & Negatif \\
\hline \hline
\end{tabular}

Tabel 4. Hasil Uji Kemurnian Bifidobacterium longum

\begin{tabular}{llll}
\hline \multicolumn{1}{c}{ Uji } & & Hasil Uji & Du dkk., (1998) \\
\hline \hline Bentuk Sel & Batang & Batang & \\
Pengecatan Gram & Positif & Positif & Non-motil \\
Motilitas & Non-motil & Negatif & \\
Katalase & Negatif & S & S \\
\hline \hline
\end{tabular}

Tabel 5. Hasil Uji Warna Yoghurt Sinbiotik dengan Kombinasi Tepung Kimpul dan Sari Buah Mangga

\begin{tabular}{ccc}
\hline \hline Kombinasi Tepung Kimpul : Sari Buah Mangga & Interpretasi Color Reader & Interpretasi Mata \\
\hline \hline K $(0: 0)$ & Sumber Cahaya (Putih) & Putih krem \\
C $(4: 10)$ & Sumber Cahaya (Putih) & Putih kekuningan \\
B (7:7) & Sumber Cahaya (Putih) & Putih kuning kecoklatan \\
A (10:4) & Sumber Cahaya (Putih) & Putih kecoklatan \\
\hline \hline
\end{tabular}

Tabel 6. Viabilitas BAL Yoghurt Sinbiotik

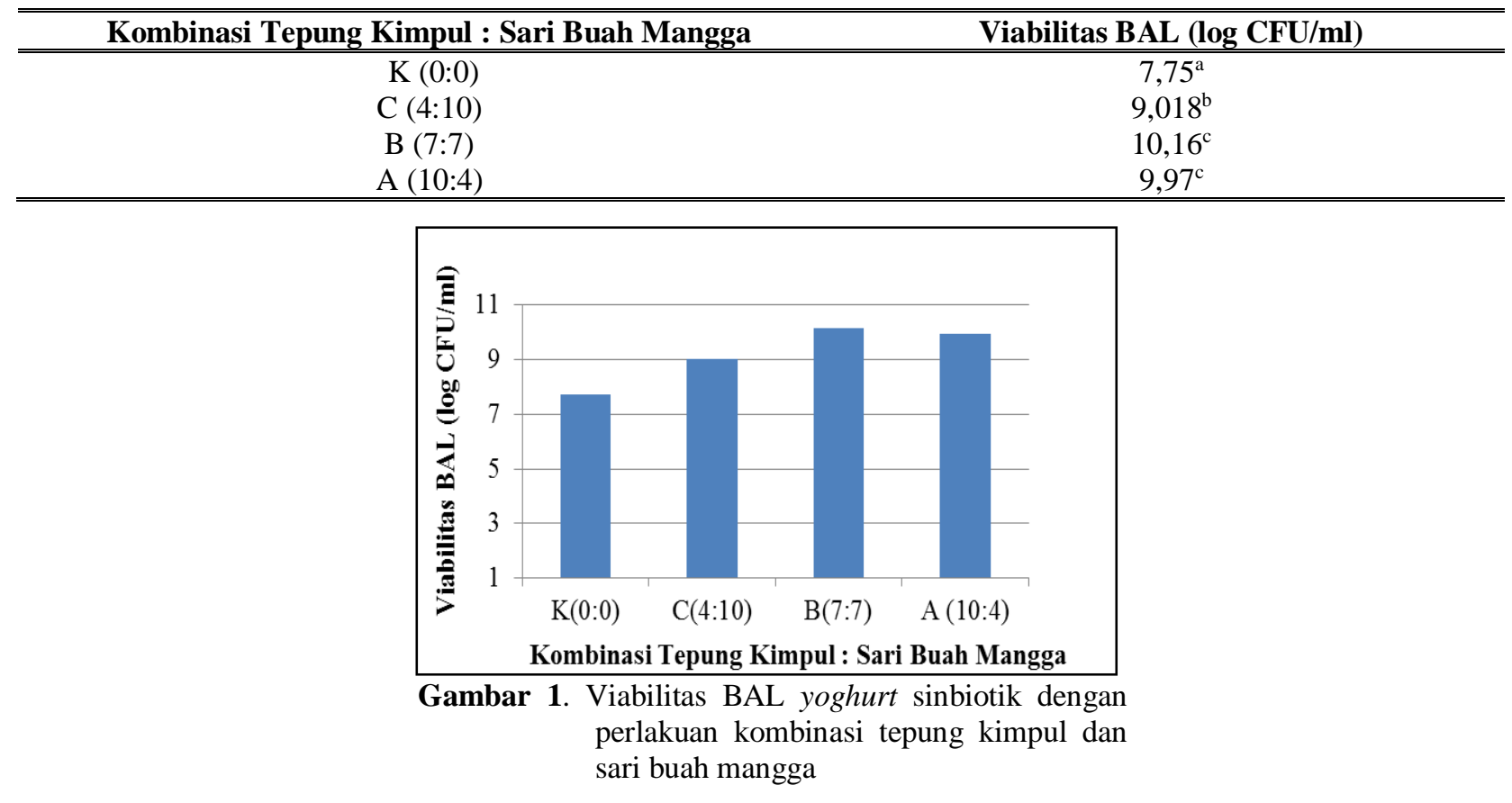


Seiring dengan penambahan tepung kimpul, maka viabilitas BAL dalam yoghurt juga semakin meningkat. Hal ini diduga adanya pengaruh kandungan karbohidrat yang terdapat di dalam tepung kimpul. Kimpul mengandung oligosakarida yang berfungsi sebagai prebiotik bagi BAL sehingga meningkatkan pertumbuhannya. Hasil penelitian ini sesuai dengan penelitian Purwijantiningsih (2007), bahwa sumber prebiotik berpengaruh terhadap viabilitas BAL. Adanya enzim $\alpha$-galaktosidase yang dimiliki Lactobacillus acidophilus dan Bifidobacterium longum membuat bakteri tersebut mampu untuk menggunakan substrat oligosakarida. Enzim $\alpha$-galaktosidase dapat memecah senyawa oligasakarida dengan memotong pada ikatan 1,6 glikosidik (Usmiati dan Utami, 2008).

\section{Analisis Salmonella Pada Yoghurt Sinbiotik}

Dari uji salmonella diperoleh hasil bahwa semua produk yoghurt perlakuan $\mathrm{K}(0: 0)$, $\mathrm{C}(4: 10), \mathrm{B}(7: 7)$, dan $\mathrm{A}(10: 4)$ menunjukkan hasil yang negatif. Menurut Badan Standarisasi Nasional (2009), syarat mutu kriteria Salmonella spp. pada yoghurt adalah harus negatif sehingga produk yoghurt penelitian ini telah sesuai dan memenuhi standar SNI sehingga aman untuk dikonsumsi. Penghambatan bakteri Salmonella juga dipengaruhi oleh proses pembuatan yoghurt dimana bahan-bahan dipasteurisasi terlebih dahulu pada suhu $70-80^{\circ} \mathrm{C}$ selama 20 menit. Penurunan $\mathrm{pH}$ dalam yoghurt juga dapat menghambat pertumbuhan mikrobia patogen hal ini dipengaruhi oleh adanya asam-asam organik yang dihasilkan selama pertumbuhan BAL.

\section{Analisis Kimia Yoghurt Sinbiotik Analisis Kadar Lemak Yoghurt Sinbiotik}

Rata-rata kadar lemak yoghurt sinbiotik berkisar antara 1,69\% hingga 1,98\% (Tabel 7). Menurut Badan Standardisasi Nasional (2009), kadar lemak yoghurt untuk kategori rendah lemak yaitu berkisar 0,6-2,9\% sehingga kadar lemak yoghurt sinbiotik semua perlakuan dari penelitian ini telah sesuai dan memenuhi syarat mutu yoghurt rendah lemak.

Hasil menunjukkan tidak adanya perbedaan nyata. Hal ini dikarenakan volume susu yang diberikan antar perlakuan adalah sama sehingga diasumsikan lemak susu yang terdapat dalam yoghurt antar perlakuan juga tidak jauh berbeda. Kadar lemak yang rendah pada yoghurt sinbiotik dapat dikarenakan adanya aktivitas lipolitik oleh BAL. Aktivitas lipolisis lemak oleh BAL akan menyebabkan menurunnya kadar lemak dalam yoghurt dan meningkatkan kadar asam laktat (Sunarlim dan Setiyanto, 2008).

Tabel 7. Kadar Lemak Yoghurt Sinbiotik

\begin{tabular}{cc}
\hline \hline Kombinasi Tepung Kimpul : Sari Buah Mangga & Kadar Lemak \\
\hline \hline K $(0: 0)$ & $1,81^{\mathrm{a}}$ \\
C (4:10) & $1,69^{\mathrm{a}}$ \\
B (7:7) & $1,82^{\mathrm{a}}$ \\
A (10:4) & $1,98^{\mathrm{a}}$ \\
\hline \hline
\end{tabular}

$\overline{\text { Keterangan : Angka yang diikuti huruf yang sama pada setiap kolom yang sama menunjukkan tidak beda nyata }(\alpha=}$ $0,05)$

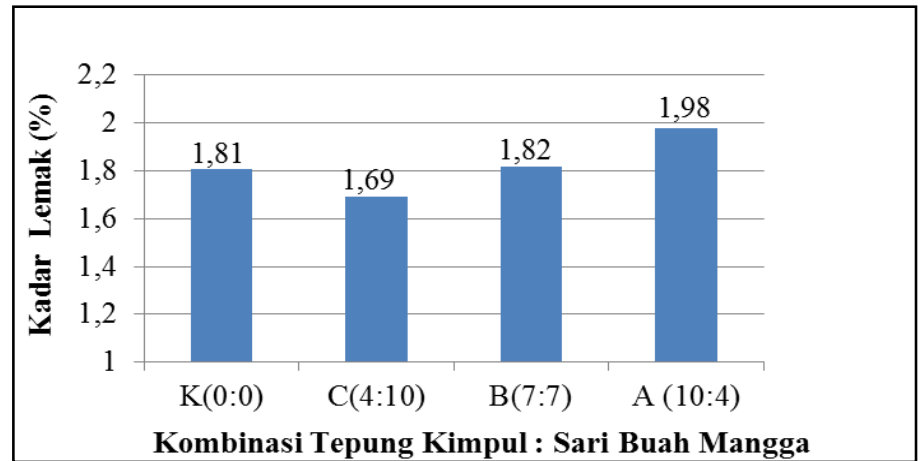

Gambar 2. Kadar lemak (\%) yoghurt sinbiotik dengan perlakuan kombinasi tepung kimpul dan sari buah mangga 


\section{Analisis Kadar Protein Yoghurt Sinbiotik}

Menurut Badan Standarisasi Nasional (2009), syarat mutu kadar protein pada yoghurt adalah minimal 2,7\%. Berdasarkan hasil pengujian kadar protein yoghurt sinbiotik diperoleh hasil kadar protein berkisar antara $3,2 \%$ - 3,91\% (Tabel 8), sehingga produk yoghurt yang dihasilkan dari penelitian ini telah sesuai dan memenuhi standar SNI untuk syarat mutu yoghurt. Hasil kadar protein menunjukkan tidak adanya perbedaan nyata. Namun, seiring penambahan tepung kimpul menyebabkan kecenderungan kenaikan kadar protein yoghurt sinbiotik walaupun tidak memiliki perbedaan yang signifikan.

Perbedaan yang tidak signifikan tersebut bisa terjadi karena variasi antar produk yang memiliki rentang tidak terlalu jauh sehingga dihasilkan kadar protein yang tidak berbeda secara signifikan antar produk. Selain itu menurut Herawati dan Wibawa (2013), semakin banyak jumlah bakteri asam laktat yang terdapat di dalam yoghurt maka kandungan proteinnya cenderung semakin tinggi karena sebagian besar komponen penyusun bakteri adalah protein.

\section{Analisis Kadar Serat Larut Yoghurt Sinbiotik}

Hasil kadar serat larut pada yoghurt perlakuan $\mathrm{K}(0: 0), \mathrm{C}(4: 10), \mathrm{B}(7: 7)$, dan $\mathrm{A}(10: 4)$ secara berurutan yakni $2 ; 2,36 ; 2,62$ dan $3,53 \%$ (Tabel 9). Semakin banyak penambahan konsentrasi tepung kimpul menunjukkan kadar serat larut pada yoghurt sinbiotik yang semakin meningkat dan berbeda dengan perlakuan kontrol yang menunjukkan kadar serat larut paling rendah. Umbi kimpul mengandung Polisakarida Larut Air (PLA) yang dapat dimanfaatkan sebagai prebiotik karena diketahui mampu meningkatkan populasi Bifidobacterium dalam kolon. Menurut Prabowo dkk., (2014), polisakarida larut air (PLA) tidak dapat terdegradasi secara enzimatis menjadi sub-sub unit yang dapat diserap di lambung dan di usus, sehingga FOS dan inulin termasuk dalam dietary fiber.

\section{Analisis Derajat Keasaman (pH) Yoghurt Sinbiotik}

Hasil derajat keasaman $(\mathrm{pH})$ pada yoghurt perlakuan $\mathrm{K}(0: 0), \mathrm{C}(4: 10), \mathrm{B}(7: 7)$, dan $\mathrm{A}(10: 4)$ secara berurutan yakni 4,24; 4; 3,94; dan 3,95 (Tabel 10). Semakin rendah nilai $\mathrm{pH}$ yoghurt maka semakin baik karena $\mathrm{pH}$ yang rendah menandakan proses fermentasi oleh BAL dalam yoghurt berlangsung dengan baik.

Analisis nilai $\mathrm{pH}$ seluruh perlakuan menunjukkan peningkatan penambahan tepung kimpul cenderung menurunkan nilai $\mathrm{pH}$ yoghurt walaupun tidak memiliki perbedaan yang signifikan. Nilai $\mathrm{pH}$ pada produk yoghurt sinbiotik sangat dipengaruhi oleh jumlah BAL, total asam laktat, proses pembuatan yoghurt sinbiotik itu sendiri dan kandungan asam organik pada buah mangga dimana sari buah mangga sendiri memiliki nilai $\mathrm{pH}$ sebesar 4 (Khairunnisa, 2016).

Tabel 8. Kadar Protein Yoghurt Sinbiotik

\begin{tabular}{cc}
\hline \hline Kombinasi Tepung Kimpul : Sari Buah Mangga & Kadar Protein \\
\hline \hline K $(0: 0)$ & $3,2^{\mathrm{a}}$ \\
C (4:10) & $3,55^{\mathrm{a}}$ \\
B (7:7) & $3,84^{\mathrm{a}}$ \\
A (10:4) & $3,91^{\mathrm{a}}$ \\
\hline \hline
\end{tabular}

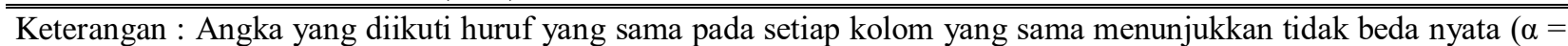
$0,05)$

Tabel 9. Kadar Serat Larut Yoghurt Sinbiotik

\begin{tabular}{cc}
\hline \hline Kombinasi Tepung Kimpul : Sari Buah Mangga & Kadar Serat Larut \\
\hline \hline K $(0: 0)$ & $2^{\mathrm{a}}$ \\
C $(4: 10)$ & $2,36^{\mathrm{a}}$ \\
B $(7: 7)$ & $2,62^{\mathrm{a}}$ \\
A $(10: 4)$ & $3,53^{\mathrm{b}}$ \\
\hline \hline
\end{tabular}

Keterangan : Angka yang diikuti huruf yang sama pada setiap kolom yang sama menunjukkan tidak beda nyata $(\alpha=$ $0,05)$ 
Tabel 10. Derajat Keasaman Yoghurt Sinbiotik

\begin{tabular}{cc}
\hline \hline Kombinasi Tepung Kimpul : Sari Buah Mangga & Nilai pH \\
\hline \hline K $(0: 0)$ & $4,24^{\mathrm{a}}$ \\
C (4:10) & $4,0^{\mathrm{b}}$ \\
B (7:7) & $3,94^{\mathrm{b}}$ \\
A (10:4) & $3,95^{\mathrm{b}}$ \\
\hline \hline
\end{tabular}

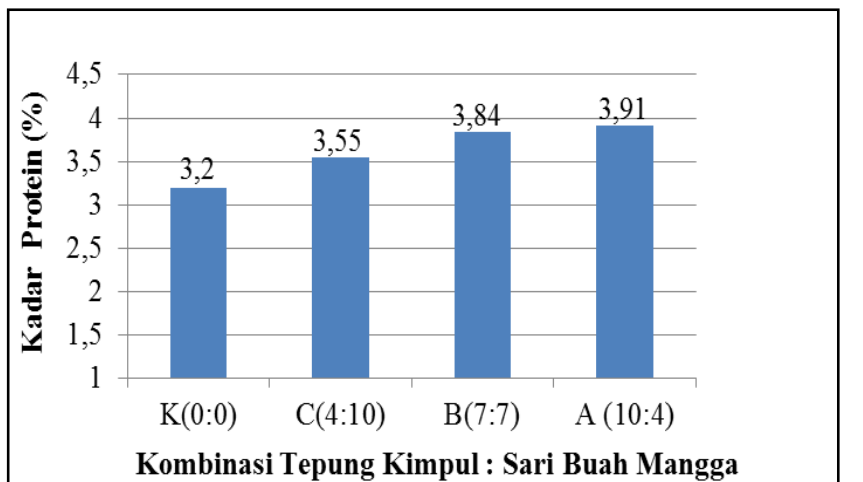

Gambar 3. Kadar protein (\%) yoghurt sinbiotik dengan perlakuan kombinasi tepung kimpul dan sari buah mangga.

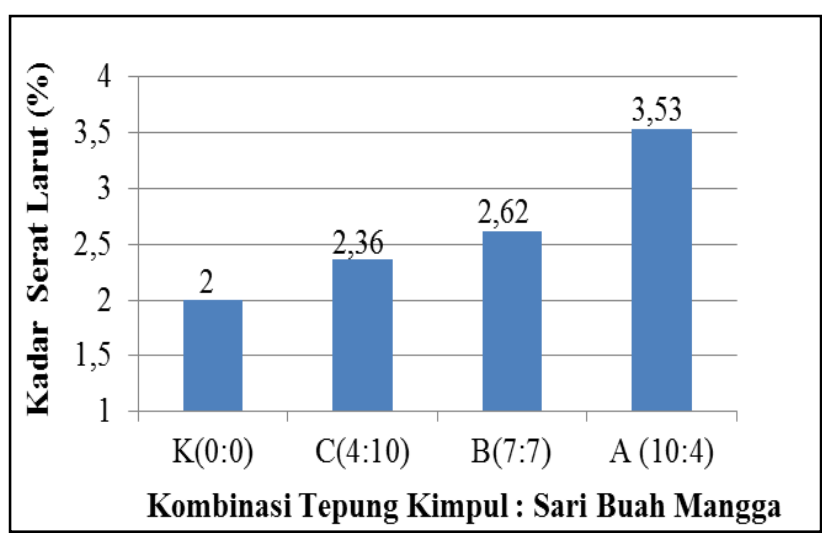

Gambar 4. Kadar serat larut (\%) yoghurt sinbiotik dengan perlakuan kombinasi tepung kimpul dan sari buah mangga.

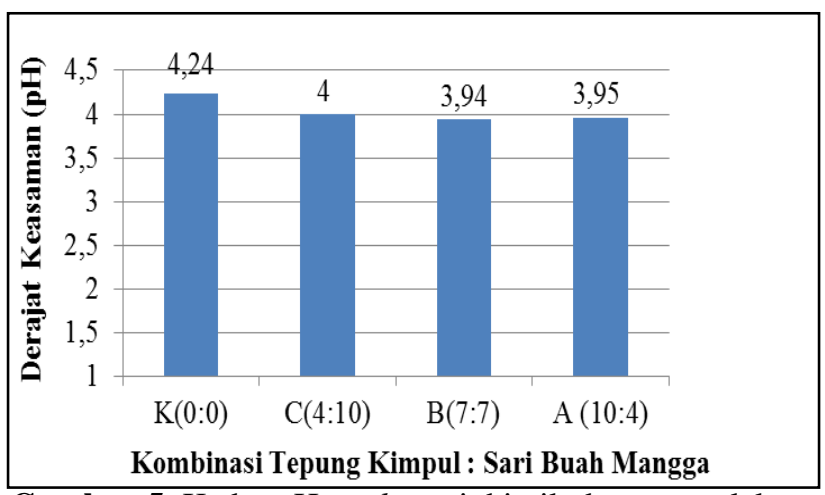

Gambar 5. Kadar $\mathrm{pH}$ yoghurt sinbiotik dengan perlakuan kombinasi tepung kimpul dan sari buah mangga. 


\section{Analisis Kadar Asam Laktat Yoghurt Sinbiotik}

Menurut Badan Standarisasi Nasional (2009), syarat mutu kadar asam laktat pada yoghurt adalah sekitar 0,5\% - 2,0\%. Berdasarkan hasil pengujian kadar asam laktat yoghurt sinbiotik diperoleh hasil kadar asam laktat berkisar antara 1,3\% - 1,79\% (Tabel 11), sehingga produk yoghurt yang dihasilkan dari penelitian ini telah memenuhi standar SNI syarat mutu yoghurt. Hasil kadar asam laktat yoghurt yang tidak berbeda nyata dapat disebabkan karena konsentrasi tepung kimpul dan sari buah mangga yang ditambahkan menghasilkan kadar asam laktat dengan selisih angka yang relatif sedikit.

Dari hasil tersebut menunjukkan bahwa penambahan tepung kimpul menghasilkan asam laktat yang cenderung semakin meningkat, meskipun tidak berbeda nyata. Hal tersebut menunjukkan adanya aktivitas BAL yang dapat memfermentasi serat inulin yang terkandung pada tepung kimpul. Dalam hal ini terutama pada Bifidobacterium longum yang bersimbiosis dengan serat jenis inulin pada tepung kimpul dan memiliki sifat heterofermentatif yang mana dapat menghasilkan asam laktat dan asam asetat (Holt dkk., 1994).

\section{Analisis Kadar Gula Reduksi Yoghurt Sinbiotik}

Hasil kadar gula reduksi pada yoghurt perlakuan $\mathrm{K}(0: 0), \mathrm{C}(4: 10), \mathrm{B}(7: 7)$, dan $\mathrm{A}(10: 4)$ sebelum inkubasi secara berurutan yakni 3,49 ; 6,36; 5,24 dan 3,93\% (Tabel 12), sedangkan kadar gula reduksi pada yoghurt perlakuan $\mathrm{K}(0: 0), \mathrm{C}(4: 10), \mathrm{B}(7: 7)$, dan $\mathrm{A}(10: 4)$ sesudah inkubasi secara berurutan yakni 2,$38 ; 3,4 ; 3,44$ dan 2,63\%. Dari hasil tersebut menujukkan bahwa kadar gula reduksi pada yoghurt sinbiotik sebelum dan sesudah inkubasi mengalami penurunan yang signifikan dan terdapat beda nyata secara statistik.

Dari hasil yang diperoleh menunjukkan bahwa seiring peningkatan penambahan sari buah mangga, hasil kadar gula reduksi juga semakin meningkat. Hal ini dikarenakan kadar gula reduksi pada yoghurt sinbiotik dipengaruhi oleh kadar gula reduksi pada buah mangga. Dari hasil uji kadar gula reduksi bahan awal, diperoleh kadar gula reduksi pada buah mangga adalah sebesar 3,3\%. Menurut Wulandari dan Putranto (2010), kandungan glukosa pada buah mangga diduga dapat dimanfaatkan untuk mendukung aktivitas dan pertumbuhan BAL. Pada penelitian ini, kadar gula reduksi pada yoghurt sinbiotik mengalami penurunan setelah diinkubasi sehingga menunjukkan bahwa kandungan gula pereduksi dalam yoghurt yang berasal dari sari buah mangga terbukti dimanfaatkan oleh BAL untuk mendukung pertumbuhannya (Tabel 12).

\section{Analisis Organoleptik Yoghurt Sinbiotik}

Uji organoleptik dilakukan pada 15 panelis berjenis kelamin laki-laki dan 15 panelis berjenis kelamin perempuan, yang rata-rata memiliki latar belakang suka terhadap produk yoghurt. Uji organoleptik meliputi parameter warna, aroma, rasa, tekstur, dan peringkat. Pada parameter warna, aroma, rasa, dan tekstur. Berdasarkan parameter warna produk yoghurt sinbiotik panelis cenderung menyukai produk $\mathrm{C}(4: 10)$, parameter aroma panelis cenderung menyukai produk $\mathrm{C}(4: 10)$, parameter rasa panelis cenderung menyukai produk $\mathrm{C}(4: 10)$, parameter tekstur panelis cenderung menyukai produk $\mathrm{C}(4: 10)$ dan $\mathrm{K}$ (0:0), dan secara keseluruhan peringkat kesukaan panelis dari yang paling disukai berturut-turut yaitu variasi perlakuan $\mathrm{C}-\mathrm{B}-\mathrm{A}-\mathrm{K}$.

Tabel 11. Kadar Asam Laktat Yoghurt Sinbiotik

\begin{tabular}{cc}
\hline \hline Kombinasi Tepung Kimpul : Sari Buah Mangga & Kadar Asam Laktat \\
\hline \hline K $(0: 0)$ & $1,3^{\mathrm{a}}$ \\
C $(4: 10)$ & $1,48^{\mathrm{ab}}$ \\
B (7:7) & $1,63^{\mathrm{ab}}$ \\
A (10:4) & $1,79^{\mathrm{b}}$ \\
\hline \hline
\end{tabular}

$\overline{\text { Keterangan : Angka yang diikuti huruf yang sama pada setiap kolom yang sama menunjukkan tidak beda nyata }(\alpha}=$ $0,05)$ 
Ngatini dkk.,

Tabel 12. Kadar Gula Reduksi (\%) Yoghurt Sinbiotik

\begin{tabular}{ccccc}
\hline \hline $\begin{array}{c}\text { Kombinasi Tepung Kimpul : } \\
\text { Sari Buah Mangga }\end{array}$ & $\begin{array}{c}\text { Sebelum } \\
\text { Inkubasi }\end{array}$ & $\begin{array}{c}\text { Sesudah } \\
\text { Inkubasi }\end{array}$ & $\begin{array}{c}\text { Paired Sample T-Test } \\
\text { Sig.(2-tailed) }\end{array}$ & Ket. \\
\hline \hline K (0:0) & $3,44 \%$ & $2,38 \%$ & 0,022 & Ada Perbedaan \\
C (4:10) & $6,36 \%$ & $3,4 \%$ & 0,031 & Ada Perbedaan \\
B (7:7) & $5,24 \%$ & $3,44 \%$ & 0,047 & Ada Perbedaan \\
A (10:4) & $3,93 \%$ & $2,63 \%$ & 0,035 & Ada Perbedaan \\
\hline \hline
\end{tabular}

Tabel 13. Hasil Uji Organoleptik Yoghurt Sinbiotik dengan Perlakuan Penambahan Tepung Kimpul dan Sari Buah Mangga

\begin{tabular}{ccccccc}
\hline \hline Kombinasi Konsentrasi (K:M) & \multicolumn{7}{c}{ Parameter } \\
\cline { 2 - 7 }$(\boldsymbol{\%})$ & Warna & Aroma & Rasa & Tekstur & Rata-rata & Peringkat \\
\cline { 2 - 7 } K (0:0) & 3,1 & 2,23 & 2,4 & 3 & 2,68 & 3,3 \\
\hline C (4:10) & 3,13 & 3,43 & 3,46 & 3 & 3,25 & 1,4 \\
B (7:7) & 2,9 & 2,96 & 3 & 2,8 & 2,91 & 2,53 \\
A (10:4) & 2,46 & 2,8 & 2,8 & 2,96 & 2,75 & 2,76 \\
\hline \hline
\end{tabular}

Keterangan : $\mathrm{K}=$ Tepung Kimpul

$\mathrm{M}=$ Sari Buah Mangga

Parameter Peringkat $=(\mathrm{C} \rightarrow \mathrm{I}),(\mathrm{B} \rightarrow \mathrm{II}),(\mathrm{A} \rightarrow \mathrm{III}),(\mathrm{K} \rightarrow \mathrm{IV})$

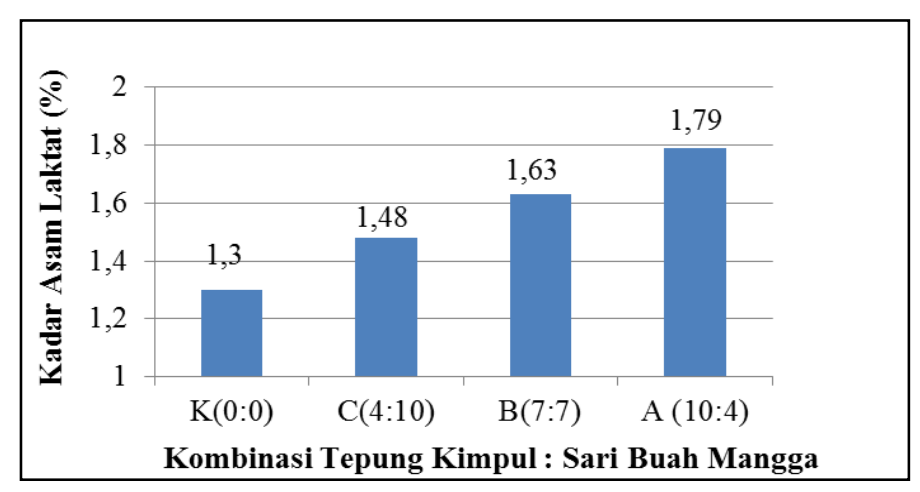

Gambar 6. Kadar asam laktat yoghurt sinbiotik dengan perlakuan kombinasi tepung kimpul dan sari buah mangga

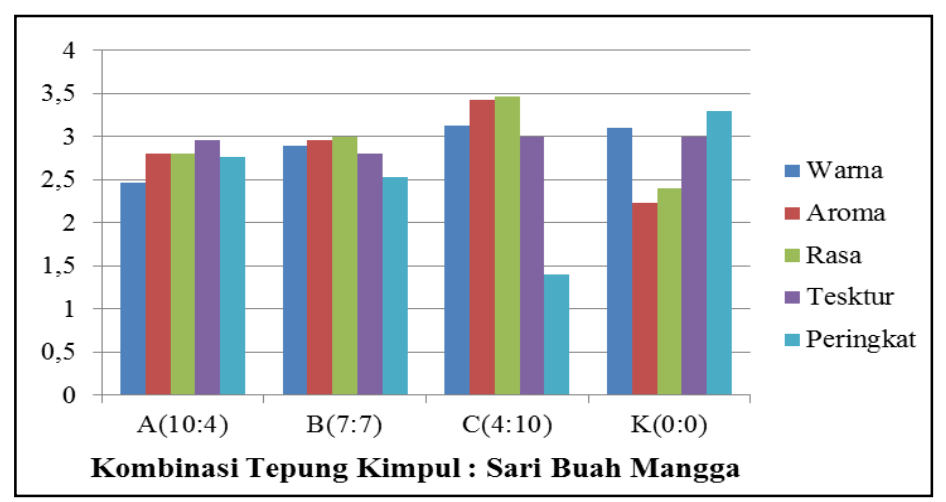

Gambar 7. Hasil Organoleptik dengan parameter warna, aroma, rasa, tekstur, dan peringkat pada yoghurt sinbiotik dengan perlakuan kombinasi tepung kimpul dan sari buah mangga pada variasi konsentrasi yang berbeda. 


\section{Simpulan dan Saran}

\section{Simpulan}

Kombinasi tepung kimpul dan sari buah mangga tidak memberikan pengaruh yang berbeda nyata terhadap kadar protein, kadar lemak, dan kadar serat larut tetapi memberikan pengaruh berbeda nyata terhadap kadar gula reduksi, derajat keasaman $(\mathrm{pH})$, kadar asam laktat dan viabilitas BAL. Kombinasi tepung kimpul $4 \%$ dan sari buah mangga $10 \%$ menghasilkan kualitas yoghurt sinbiotik yang paling baik.

\section{Saran}

Yoghurt sinbiotik yang dihasilkan dapat ditambahkan pewarna sehingga dapat menghilangkan warna kecoklatan yang berasal dari tepung kimpul.

\section{Daftar Pustaka}

Abdurachman, A., Dariah dan Mulyani. 2008. Strategi dan Teknologi Pengelolaan Lahan Kering Mendukung Pengadaan Pangan Nasional. Jurnal Litbang Pertanian, 1 (1): 24-32.

Badan Standardisasi Nasional. 2009. Yoghurt. SNI 012981-2009. Badan Standardisasi Nasional, Jakarta. Halaman 2.

Coulate, T. 2009. Food The Chemistry of its Components 5th Edition. Royal Society of Cheistry, Cambridge. Halaman 501.

Departemen Kesehatan RI. 1972. Daftar Komposisi Bahan Makanan. Direktorat Gizi Departemen Kesehatan RI, Jakarta. Halaman 57.

Du, F., Zang, S. dan Mustapha, A. 1998. Lactose transport, $\beta$ - galactosidase activity, and bile and acid tolerance of Bifidobactera. IFT Annu. Mtg: 106.

Gomez, A.M.P. dan Malcata, F.X. 1999. Bifidobacterium spp. and Lactobacillus acidophilus: biological, biochemical, technological and therapeutical properties relevant for use as probiotics. Trends in Food Science \& Technology, 10 (1): 139157.

Herawati, D.A. dan wibawa, A.A. 2011. Pengaruh Konsentrasi Susu Skim Dan Waktu Fermentasi Terhadap Hasil Pembuatan Soyghurt. Jurnal ilmiah teknik lingkungan, 1 (2): 48-58.
Hidayat, I.R., Kusrahayu dan Mulyani, S. 2013. Total bakteri asam laktat, nilai ph dan sifat organoleptik drink yoghurt dari susu sapi yang diperkaya dengan ekstrak buah mangga. Animal Agriculture Journal, 2 (1): 160-167.

Holt, J.G., Krieg, N.R., Sneath, P.H.A., Staley, J.T. dan Williams S.T. 1994. Bergey's Manual of Determinative Bacteriology. Ninth edition. The Williams and Wilkins Co., Baltimore. Halaman 596.

Hossain, Md. Anowar., Rana, Md. Masud., Kimura, Yoshinobu dan Roslan, H.A. 2014. Changes in Biochemical Characteristics and Activities of Ripening Associated Enzymes in Mango Fruit during the Storage at Different Temperatures. BioMed Research International, Volume 2014: 1-11. DOI:10.1155/2014/232969

Jatmiko, G.P. 2013. Karakteristik Fisiko Kimia, Bioaktif dan Organoleptik Mie Dari Umbi Kimpul (Xanthosoma sagittifolium). Skripsi. Universitas Brawijaya, Malang.

Kartikorini, N. 2016. Analisa kadar gula (sukrosa) buah mangga berdasarkan varietasnya. The JaMMiLT, 2 (1): 28-32.

Khairunnisa, L. 2016. Formulasi sediaan krim sari buah mangga (Mangifera indica L.) sebagai pelembab kulit. Skripsi. Fakultas Farmasi. USU, Medan.

Lesniewska, V., Rowland, I., Cani, P.D., Neyrinck, A.M., Delzenne, N.M. dan Naughton, P.J. 2006. Effect on component of Intestinal Microflora and Plasma Neuropeptide Levels of Feeding Lactobacillus delbrueckii, Bifidobacterium lactis and Inulin to Adult and Elderly Rats. Appl. \& Env. Microbiol, 72 (10): 6533-6538

Pangaribuan, A.D. 2013. Substitusi Tepung Talas Belitung pada Pembuatan Biskuit Daun Kelor (Moringa oleifera Lamk.). Skripsi S-1. Fakultas Teknobiologi Universitas Atma Jaya Yogyakarta, Yogyakarta.

Prabowo, A. Y., Estiasih, T. dan Purwantiningrum, I. 2014. Umbi Gembili (Dioscorea esculenta L.) sebagai Bahan Pangan Mengandung Senyawa Bioaktif : Kajian Pustaka. Jurnal Pangan dan Agroindustri, 2 (3): 129-135.

Purwandani, S.N. dan Rahayu, E.S. 2003. Isolasi dan Identifikasi Lactobacillus yang Berpotensi sebagai Agensia Probiotik. Jurnal Agritech, 23 (2): 67-64.

Purwijantiningsih, E. 2007. Pengaruh Jenis Prebiotik terhadap Kualitas Yogurt Probiotik. Biota, 12 (3): 177-185.

Ramulu, P. dan Rao, P.U. 2003. Total, insoluble and soluble dietary fiber contents of Indian fruits. Journal of Food Composition and Analysis, 16 (1): 677-685. 


\section{Ngatini dkk.,}

Senditya, M., Hadi, M.S., Estiasih, T. dan Saparianti, E. 2014. Efek prebiotik dan sinbiotik simplisia daun cincau hitam (Mesona palustris BL) secara in vivo: kajian pustaka. Jurnal Pangan dan Agroindustri, 2 (3):141-151.

Sunarlim, R. dan Setiyanto, H. 2008. Pengaruh Kombinasi Lactobacillus acidophillus dengan Starter Yoghurt (Lactobacillus bulgaricus dan Streptococcus thermophillus) terhadap Mutu Susu Fermentasi. Seminar Nasional Teknologi Peternakan dan Veteriner. Halaman 317-326.
Usmiati, S. dan Utami, T. 2008. Pengaruh bakteri probiotik terhadap mutu sari kacang tanah fermentasi. Jurnal Pascapanen, 5 (2): 27-36.

Wulandari, E. dan Putranto, W.S. 2010. Karakteristik Stirred Yoghurt Mangga (Mangifera indica) dan Apel (Malus domestica) Selama Penyimpanan. Jurnal Ilmu Ternak, 10 (1): 14-16. 